\title{
The Effect of Liquid Organic Fertilizer From Coconut Husk And Dolomite On Shallot (Allium Cepa L.) Growth And Yield
}

\author{
Kamelia Dwi Jayanti 1, Yulinda Tanari ${ }^{*}$ \\ ${ }^{1}$ Department of Agrotechnology, Faculty of Agriculture, Universitas Sintuwu Maroso. Indonesia \\ Pulau Timor No. 1 Poso, Sulawesi Tengah, Indonesia \\ *Corresponding author: yulinda@unsimar.ac.id
}

\section{ARTICLE HISTORY \\ Received : 12 July 2021 \\ Revised : 22 September 2021 \\ Accepted : 15 October 2021}

\section{KEYWORDS}

Potassium;

Calcium;

Magnesium;

Fresh shallot bulbs weight;

\begin{abstract}
Shallot is the most produced vegetable in Indonesia. The consumption of shallot per $\mathrm{kg}$ /capita/year is continuously increasing, therefore there is a need to ensure enough supply. The lack of nutrients in the soil is a problem in shallot production. Shallot needs macronutrients such as Nitrogen $(\mathrm{N})$, Phosphorus $(\mathrm{P})$, Potassium $(\mathrm{K})$, and Calcium $(\mathrm{Ca})$ to improve its yield and quality. The application of liquid organic fertilizer from coconut husk and dolomite can be the solution. This study was conducted using Factorial Randomized Block Design consisting of two factors, concentration of liquid organic fertilizer $(0 \%, 10 \%, 20 \%$, and $30 \%)$ and dolomite (with dolomite or without). The results showed that the application of $20 \%$ liquid organic fertilizer, the application of dolomite, and the combination of both $\left(\mathrm{P}_{2} \mathrm{D}_{1}\right)$ had the highest value on fresh shallot bulbs weight per clumps and bulb weight after storage parameters, and had the lowest value on weight loss percentage parameter.
\end{abstract}

This is an open access article under the CC-BY-SA license.

\section{INTRODUCTION}

One of nine national research main priorities is to encourage the development and utilization of domestic products, that includes food, plantations, and horticulture (Ristekdikti, 2020). In the horticulture sector, shallot, garlic, and chili pepper are commodities that received attention to be developed.

Shallot is an annual crop with $90 \%$ of edible part. The nutrient compositions of shallot per 100 grams are calorie of $39 \mathrm{kcal}$, protein of $2.50 \mathrm{~g}$, and fat $0.30 \mathrm{~g}$.

Shallot was the highest produced vegetables in Indonesia, followed by cabbage and cayenne pepper (Central Bureau of Statistic 2018), and also placed second in vegetable export in the same year. Shallot productivity in 2018 was 9,59 ton/ha, higher than previous years that was 8,37 ton/ha in 2016 and 9.06 ton/ha in 2017 (CBS 2019). Even the productivity was increasing, it is still important to continue developing this commodity to ensure national food security. According to the Ministry of Agriculture (2019), there was an increase in shallot consumption from $2.57 \mathrm{~kg} /$ capita/year in 2017 to 2,76 $\mathrm{kg} / \mathrm{capita} / \mathrm{year}$ in 2018.

One of the national research targets for 2020 - 2024 is to increase the national productivity of shallot (Ristekdikti, 2020). According to data from the Ministry of
Agriculture (2018), increasing the productivity of shallots can be done by expanding the planting area and also improving cultivation technology. Improvements in cultivation technology can be done by adding nutrients to the soil and plants. Based on the research results, in addition to the elements $\mathrm{N}, \mathrm{P}$ and $\mathrm{K}$, shallot plants also need calcium ( $\mathrm{Ca}$ ) to increase yield and quality.

Calcium is an important element in the formation of cell walls. Ca2+ is the link between the pectin chain in the cell wall structure (Taiz and Zeiger 2010; Marschner 2012). Based on this function, it is assumed that the application of calcium will increase the integrity of the shallot cell wall and so that it has a longer shelf life.

One type of fertilizer that has a high amount of $\mathrm{Ca}$ is dolomite ( $\left.\mathrm{CaMg}(\mathrm{CO})_{3}\right)_{2}$. According to Buckman and Brady (1982), dolomite is a farming lime that can add Ca and Magnesium (Mg) to meet the need of plants and can improve the physical property of the soil, and does not leave harmful residue in the soil. According to research results from Handayani (2017) application of 1,5 ton/ha dolomite at 4 weeks before planting resulted in a significantly higher number and weight of bulbs per clump, and significantly lower weight loss compared to an application at planting and application two weeks before planting.

Apart from dolomite, a fertilizer that is thought to 
increase the productivity of shallots is liquid organic fertilizer (LOF) made from coconut husk. Coconut husk liquid organic fertilizer contains $\mathrm{N}$ of $1,58 \%, \mathrm{P}_{2} \mathrm{O}_{5}$ of $0,79 \%$ and $\mathrm{K}_{2} \mathrm{O}$ of $1,68 \%$ (Suriadi 2020).

Based on the description, it was deemed necessary to research the application of coconut husk LOF and dolomite to increase the yield and quality of shallots.

\section{MATERIALS AND METHODS}

This study was conducted in Ranononcu Sub-district, Poso District, on July - December 2020.

\subsection{Experimental Design}

This study was arranged using Factorial Randomized Block Design with 2 factors. The first factor (Factor A) was the application of dolomite with two levels of treatments:

D0 = control

D1 = 10 ton/ha dolomite

The second factor (Factor B) was the application of liquid organic fertilizer consisted of four levels of treatments:

$\mathrm{P} 0=$ control

$\mathrm{P} 1=\mathrm{LOF}$ concentration of $10 \%$

P2 = LOF concentration of $20 \%$

P3 = LOF concentration of $30 \%$

There were 8 combinations of treatments. Every combination was replicated three times, so there were 24 experimental units. Each experimental unit consisted of 5 polybags, so there were 120 polybags in total. The parameters observed were plant height, number of leaves per clump, bulb diameter, fresh bulb weight per clump, bulb weight after storage per clump, and the weight loss percentage.

\subsection{Production of Coconut Husk Liquid Organic Fertilizer}

Chopped coconut husk was mixed with brown sugar and EM4 solution, put in a sealed container, and fermented for two weeks.

\subsection{Planting}

The bulbs for seed were treated by submerging with dithane-45 solution for 30 minutes. The top third of the bulb was cut before planted. One bulb was planted in each planting hole.

\subsection{Statistical Data Analysis}

Data collected from the study were analyzed using analysis of variance and continued with further testing using Duncan Multiple Range Test at $5 \%$ or $1 \%$.

\section{RESULTS AND DISCUSSIONS}

\subsection{Plant Height}

Analysis of variance result showed that treatments applied did not significantly affect plant height. The average plant height is shown in Table 1.

Table 1. Average plant height at 2, 3, 4 and 5 WAP

\begin{tabular}{|c|c|c|c|c|}
\hline \multirow{2}{*}{ Treatment } & \multicolumn{4}{|c|}{ Plant Height (cm) at (WAP) } \\
\hline & 2 & 3 & 4 & 5 \\
\hline \multicolumn{5}{|c|}{ Factor A (Concentration of LOF) } \\
\hline $\mathrm{P}_{0}$ & 18,80 & 24,45 & 26,75 & 29,85 \\
\hline $\mathrm{P}_{1}$ & 20,76 & 25,37 & 27,84 & 29,83 \\
\hline $\mathrm{P}_{2}$ & 20,85 & 26,50 & 29,11 & 30,49 \\
\hline $\mathrm{P}_{3}$ & 19,59 & 27,06 & 29,39 & 30,99 \\
\hline \multicolumn{5}{|c|}{ Factor B (Application of Dolomit) } \\
\hline $\mathrm{D}_{0}$ & 19,81 & 26,03 & 28,06 & 30,00 \\
\hline $\mathrm{D}_{1}$ & 20,20 & 25,67 & 28,49 & 30,59 \\
\hline \multicolumn{5}{|l|}{ Factor A x B } \\
\hline $\mathrm{P}_{0} \mathrm{D}_{0}$ & 19,13 & 25,64 & 27,69 & 30,27 \\
\hline $\mathrm{P}_{1} \mathrm{D}_{0}$ & 20,42 & 25,80 & 27,85 & 29,33 \\
\hline $\mathrm{P}_{2} \mathrm{D}_{0}$ & 21,35 & 27,20 & 29,43 & 30,97 \\
\hline $\mathrm{P}_{3} \mathrm{D}_{0}$ & 18,32 & 25,46 & 27,27 & 29,42 \\
\hline $\mathrm{P}_{0} \mathrm{D}_{1}$ & 18,47 & 23,27 & 25,81 & 29,44 \\
\hline $\mathrm{P}_{1} \mathrm{D}_{1}$ & 21,10 & 24,93 & 27,83 & 30,34 \\
\hline $\mathrm{P}_{2} \mathrm{D}_{1}$ & 20,35 & 25,81 & 28,80 & 30,02 \\
\hline $\mathrm{P}_{3} \mathrm{D}_{1}$ & 20,87 & 28,66 & 31,52 & 32,57 \\
\hline
\end{tabular}

Means followed by the same letters are not significantly different based on the DMRT test at 0.05 level

A nutrient that plays an important role in plant growth is Nitrogen. The optimal availability of $\mathrm{N}$ will have an impact on better plant growth and yield. Although, when $\mathrm{N}$ availability is low, the result would not be different from the control or without the addition of fertilizers. Nitrogen plays the most important role in various physiological processes such as giving plants a dark green color, increasing the number of leaves and stems, as well as the growth and development of other vegetative parts (Leghari et al. 2016). Sufficient Mg nutrient in plants is very important for better efficiency of $\mathrm{N}$ use (Cakmak 2013). 


\subsection{Number of Leaves}

Analysis of variance result showed that treatment of a single factor of liquid organic fertilizer and dolomite, as well as the combination of both factors, did not significantly affect the number of leaves. The average number of leaves is presented in Table 2.

Table 2. Average number of leaves at 2,3,4 and 5 WAP

\begin{tabular}{|c|c|c|c|c|}
\hline \multirow{2}{*}{ Treatment } & \multicolumn{4}{|c|}{ Number of leaves at (WAP) } \\
\hline & 2 & 3 & 4 & 5 \\
\hline \multicolumn{5}{|c|}{ Factor A (Concentration of LOF) } \\
\hline $\mathrm{P}_{0}$ & 8,43 & 12,60 & 19,58 & 23,52 \\
\hline $\mathrm{P}_{1}$ & 9,27 & 13,57 & 17,61 & 24,03 \\
\hline $\mathrm{P}_{2}$ & 9,43 & 13,25 & 19,47 & 25,70 \\
\hline $\mathrm{P}_{3}$ & 8,90 & 13,80 & 19,77 & 26,62 \\
\hline \multicolumn{5}{|l|}{$\begin{array}{l}\text { Factor B (Application of } \\
\text { Dolomite) }\end{array}$} \\
\hline $\mathrm{D}_{0}$ & 8,65 & 13,15 & 18,85 & 26,33 \\
\hline $\mathrm{D}_{1}$ & 9,37 & 13,46 & 19,36 & 23,60 \\
\hline \multicolumn{5}{|l|}{ Factor A x B } \\
\hline $\mathrm{P}_{0} \mathrm{D}_{0}$ & 7,93 & 13,27 & 20,53 & 27,27 \\
\hline $\mathrm{P}_{1} \mathrm{D}_{0}$ & 8,67 & 13,07 & 15,87 & 26,40 \\
\hline $\mathrm{P}_{2} \mathrm{D}_{0}$ & 10,00 & 13,60 & 20,07 & 25,93 \\
\hline $\mathrm{P}_{3} \mathrm{D}_{0}$ & 8,00 & 12,67 & 18,93 & 25,73 \\
\hline $\mathrm{P}_{0} \mathrm{D}_{1}$ & 8,93 & 11,93 & 18,62 & 19,77 \\
\hline $\mathrm{P}_{1} \mathrm{D}_{1}$ & 9,87 & 14,07 & 19,36 & 21,67 \\
\hline $\mathrm{P}_{2} \mathrm{D}_{1}$ & 8,87 & 12,90 & 18,87 & 25,47 \\
\hline $\mathrm{P}_{3} \mathrm{D}_{1}$ & 9,80 & 14,93 & 20,60 & 27,50 \\
\hline
\end{tabular}

Means followed by the same letters are not significantly different based on the DMRT test at 0.05 level

A similar result was showed in Sebastian (2019), that the application of coconut husk LOF was not significantly affected the number of leaves, even when combined by Gandasil fertilizer. In contrast with the study by Wilman et al. (2009), $\mathrm{N}$ was significantly affected the number of tillers and leaves.

The level of $\mathrm{N}$ in coconut husk LOF was presumed to be not optimal to affect the number of leaves, so there was no significant difference from the control.

\subsection{Number of Bulbs per Clump, Bulb Diameter, and Fresh Bulb Weight per Clum}

Table 3 shows that the treatments did not significantly affect the number of bulbs per clump. While in bulb diameter parameter, only application of dolomite treatment demonstrated a significant effect.

One of the nutrients in dolomite is Magnesium. Magnesium plays a role in carbohydrate synthesis that would be stored in the bulb. Magnesium and Nitrogen are constituents of chlorophyll (Winarso 2005), the proportion is $2,7 \%$ of chlorophyll molecule weight and is the activators of many enzymes (Yan and Hou 2018), thus $\mathrm{Mg}$ and $\mathrm{N}$ affected photosynthesis and carbohydrate partition in a plant (Wang et al. 2019).

The highest fresh bulb weight per clump resulted from the single factor of $\mathrm{P}_{2}(20 \%$ of LOF), the application of dolomite $\left(\mathrm{D}_{1}\right)$, and the combination of both $\left(\mathrm{P}_{2} \mathrm{D}_{1}\right)$. The higher dosage of LOF to $30 \%$ resulted in lower fresh bulb weight. Research by Romiyadi and Sufiadi (2015) also showed that the higher concentration of liquid coconut husk immersion, the lower the fruit weight yielded.

The potassium level in coconut husk is quite high, so fertilizer made from coconut husk can be the alternative for $\mathrm{KCl}$. Potassium in coconut husk liquid organic fertilizer plays a role in the transportation of photosynthate to the bulbs, thus can increase the fresh weight of shallot. According to Rahma et al. (2019), PPPP (2017), and Torillo Jr and Mihara (2012). Potassium in coconut husk LOF is $2,48 \%$ to $10,25 \%$, while $N$-total and P-total in coconut husk are $0,1138 \mathrm{mg} \mathrm{N} / \mathrm{g}$ and $0,3037 \mathrm{mg} \mathrm{P} / \mathrm{g}$ respectively.

\subsection{Bulb Weight after Storage and Percentage of Weight Loss}

The single factor and interaction of both factors gave a significant effect on bulb weight after storage and percentage of weight loss. The average bulb weight after storage and percentage of weight loss is shown in Table 4.

The treatment of $\mathrm{P}_{2} \mathrm{D}_{1}$ resulted in the highest bulb weight after storage, while the highest weight loss resulted from control. According to Muchtadi (1992), the weight loss of vegetables and fruits during storage is mainly because of water loss through transpiration. Calcium has several functions, one of which is to maintain the stability of the cell wall and can reduce weight loss. According to Thor (2019), Calcium is an important factor for cell wall and membrane stability. When Ca supply is low or the transportation of $\mathrm{Ca}$ is interrupted, local calcium shortage occurs, which can cause membrane damage and/or cell wall failure (Hocking et al. 2016). The high content of $\mathrm{K}$ in coconut husk liquid organic fertilizer can increase plant fresh weight through the increase of the number of cells and reduce transpiration (Center for Plantation Research and Development, 2017). 
Table 3. Average number of bulbs per clump, bulb diameter and bulb fresh weight per clump

\begin{tabular}{|c|c|c|c|}
\hline Treatment & $\begin{array}{l}\text { Number of Bulbs per Clump } \\
\text { (bulb) }\end{array}$ & Bulb Diameter (mm) & $\begin{array}{l}\text { Fresh Bulb Weight per Clump } \\
(\mathrm{g})\end{array}$ \\
\hline \multicolumn{4}{|c|}{ Factor A (Concentration of LOF) } \\
\hline $\mathrm{P}_{0}$ & 6,08 & 14,65 & $16,87 \mathrm{~b}$ \\
\hline $\mathrm{P}_{1}$ & 5,68 & 14,66 & $16,25 b$ \\
\hline $\mathrm{P}_{2}$ & 6,64 & 15,62 & $21,19 \mathrm{a}$ \\
\hline $\mathrm{P}_{3}$ & 5,68 & 14,44 & $15,55 \mathrm{~b}$ \\
\hline \multicolumn{4}{|c|}{ Factor B (Application of Dolomite) } \\
\hline $\mathrm{D}_{0}$ & 6,19 & $14,11 b$ & $15,24 b$ \\
\hline $\mathrm{D}_{1}$ & 5,85 & $15,57 \mathrm{a}$ & $19,69 \mathrm{a}$ \\
\hline \multicolumn{4}{|l|}{ Factor $\mathrm{A} \times \mathrm{B}$} \\
\hline $\mathrm{P}_{0} \mathrm{D}_{0}$ & 7,18 & 14,79 & $18,37 b$ \\
\hline $\mathrm{P}_{1} \mathrm{D}_{0}$ & 5,60 & 13,93 & $15,30 \mathrm{bc}$ \\
\hline $\mathrm{P}_{2} \mathrm{D}_{0}$ & 6,80 & 13,58 & $13,93 \mathrm{bc}$ \\
\hline $\mathrm{P}_{3} \mathrm{D}_{0}$ & 5,17 & 14,13 & $13,38 c$ \\
\hline $\mathrm{P}_{0} \mathrm{D}_{1}$ & 4,97 & 14,50 & $15,38 \mathrm{bc}$ \\
\hline $\mathrm{P}_{1} \mathrm{D}_{1}$ & 5,75 & 15,39 & $17,21 \mathrm{bc}$ \\
\hline $\mathrm{P}_{2} \mathrm{D}_{1}$ & 6,48 & 17,65 & $28,45 a$ \\
\hline $\mathrm{P}_{3} \mathrm{D}_{1}$ & 6,20 & 14,76 & $17,73 \mathrm{bc}$ \\
\hline
\end{tabular}

Means followed by the same letters are not significantly different based on the DMRT test at 0.05 level

Table 4. Average of bulb weight after storage and percentage of weight loss

\begin{tabular}{|c|c|c|c|c|c|}
\hline \multirow{2}{*}{ Treatment } & \multicolumn{4}{|c|}{ Bulb weight (g) at storage duration (WAS) } & \multirow{2}{*}{$\begin{array}{c}\text { Percentage of } \\
\text { weight loss (\%) }\end{array}$} \\
\hline & 1 & 2 & 3 & 4 & \\
\hline \multicolumn{6}{|c|}{ Factor A (Concentration of LOF) } \\
\hline $\mathrm{P}_{0}$ & $12,70 \mathrm{~b}$ & $10,73 b$ & $8,37 \mathrm{~b}$ & $7,24 b$ & $56,35 b$ \\
\hline $\mathrm{P}_{1}$ & $12,84 \mathrm{~b}$ & $10,93 b$ & $9,52 b$ & $8,95 b$ & $45,45 \mathrm{ab}$ \\
\hline $\mathrm{P}_{2}$ & $18,33 a$ & $16,77 \mathrm{a}$ & $15,42 \mathrm{a}$ & $14,30 \mathrm{a}$ & $37,29 \mathrm{a}$ \\
\hline $\mathrm{P}_{3}$ & $12,58 \mathrm{~b}$ & $10,95 \mathrm{~b}$ & $9,70 \mathrm{~b}$ & $8,64 b$ & $42,79 \mathrm{a}$ \\
\hline \multicolumn{6}{|c|}{ Factor B (Application of Dolomite) } \\
\hline $\mathrm{D}_{0}$ & $11,37 \mathrm{~b}$ & $10,01 b$ & $8,37 \mathrm{~b}$ & $7,31 b$ & $50,90 \mathrm{~b}$ \\
\hline $\mathrm{D}_{1}$ & $16,85 a$ & $14,68 \mathrm{a}$ & $13,14 \mathrm{a}$ & $12,25 \mathrm{a}$ & $40,04 a$ \\
\hline \multicolumn{6}{|l|}{ Factor $\mathrm{A} \times \mathrm{B}$} \\
\hline $\mathrm{P}_{0} \mathrm{D}_{0}$ & $13,27 b$ & $11,08 \mathrm{~b}$ & $7,62 b$ & $6,85 b$ & $62,86 c$ \\
\hline $\mathrm{P}_{1} \mathrm{D}_{0}$ & $11,50 \mathrm{~b}$ & $10,30 \mathrm{~b}$ & $8,90 \mathrm{~b}$ & $7,60 \mathrm{~b}$ & $50,28 \mathrm{bc}$ \\
\hline $\mathrm{P}_{2} \mathrm{D}_{0}$ & $10,20 \mathrm{~b}$ & $9,54 b$ & $8,44 b$ & $6,81 b$ & $50,42 \mathrm{bc}$ \\
\hline $\mathrm{P}_{3} \mathrm{D}_{0}$ & $10,50 \mathrm{~b}$ & $9,13 \mathrm{~b}$ & $8,50 \mathrm{~b}$ & $8,00 \mathrm{~b}$ & $40,05 \mathrm{ab}$ \\
\hline $\mathrm{P}_{0} \mathrm{D}_{1}$ & $12,13 \mathrm{~b}$ & $10,38 \mathrm{~b}$ & $9,13 b$ & $7,63 b$ & $49,84 b c$ \\
\hline $\mathrm{P}_{1} \mathrm{D}_{1}$ & $14,18 \mathrm{~b}$ & $11,56 \mathrm{~b}$ & $10,14 \mathrm{~b}$ & $10,30 \mathrm{~b}$ & $40,63 \mathrm{ab}$ \\
\hline $\mathrm{P}_{2} \mathrm{D}_{1}$ & $26,45 a$ & $24,00 \mathrm{a}$ & $22,40 \mathrm{a}$ & $21,80 a$ & $24,16 a$ \\
\hline $\mathrm{P}_{3} \mathrm{D}_{1}$ & $14,65 \mathrm{~b}$ & $12,78 \mathrm{~b}$ & $10,90 \mathrm{~b}$ & $9,28 b$ & $45,52 \mathrm{bc}$ \\
\hline
\end{tabular}

Note: Mean followed by the same letters are not significantly different based on the DMRT test at 0.05 level

\section{CONCLUSIONS}

Based on the obtained results, it can be concluded that:

The single factor of application of liquid organic fertilizer and application of dolomite and the combination of both factors were significant to very significant on parameters fresh bulb weight, bulb weight after storage and percentage of weight loss.

The treatment of $20 \%$ LOF concentration gave the highest value on fresh bulb weight and bulb weight after storage, and also gave the lowest percentage of weight loss.

The application of dolomite resulted in higher bulb diameter, fresh bulb weight and bulb weight after storage, and also a lower percentage of weight loss compared to without the application of dolomite.

The combination of treatments/interaction between the concentration of $20 \%$ liquid organic fertilizer and dolomite application resulted in the highest fresh bulb weight and bulb weight after storage, and also gave the lowest percentage of weight loss.

\section{REFERENCES}

[BPS] Badan Pusat Statistik (2018) Statistik Tanaman Sayuran dan Buah-buahan Semusim. Jakarta

[BPS] Badan Pusat Statistik (2019) Statistik Tanaman Sayuran Dan Buah 2018. Jakarta

Buckman HO and Brady NC (1982) Dasar Ilmu Tanah. Terjemahan Soegiman. Bharatara Karya Aksara. Jakarta.

Cakmak, I. (2013). Magnesium in crop production, food quality and human health. Plant Soil, 368, 1-4. doi: 10.1007/s11104-013-1781-2.

Handayani R (2017) Pertumbuhan, Hasil Dan Kualitas Bawang Merah (Allium ascalonicum L.) Pada Berbagai Waktu Pemberian Dolomit Dan Dosis Pupuk Organik Granule. [Script]. Universitas Sintuwu Maroso. Poso.

Hocking, B., Tyerman, S. D., Burton, R. A., \& Gilliham, M. (2016). Fruit calcium: transport and physiology. Frontiers in Plant Science, 7, 569. doi: $10.3389 /$ fpls.2016.00569.

Kementerian Pertanian (2019) Buletin Konsumsi Pangan. Pusat Data dan Informasi Kementerian Pertanian. Jakarta.

Leghari, S. J., Wahocho, N. A., Laghari, G. M., HafeezLaghari, A., MustafaBhabhan, G., HussainTalpur, K., Bhutto, T. A., Wahocho, S. A \& Lashari, A. A. (2016). Role of nitrogen for plant growth and development: A review. Advances in Environmental Biology, 10(9), 209-219. 
Marschner, H. (2012). Marschner's mineral nutrition of higher plants. Vol. 89.

Muchtadi (1992). Fisiologi Pasca Panen Sayuran dan Buah-Buahan. Departemen Pendidikan dan Kebudayaan. Direktorat Jenderal Pendidikan Tinggi. Pusat Antar Universitas. Institut Pertanian Bogor. . Bogor.

Pusat Data dan Sistem Informasi Pertanian. 2014. Buletin Konsumsi Pangan Volume 5 No. 1. https://pusdatin.setjen.pertanian.go.id

[PPPP] Pusat Penelitian dan Pengembangan Perkebunan (2017) Pemanfaatan Sabut Kelapa Sebagai Sumber Kalium Organik. Warta Penelitian dan Pengembangan Tanaman Industri, 23(1), 1-4

Rahma, S., Rasyid, B., \& Jayadi, M. (2019). Peningkatan Unsur Hara Kalium dalam Tanah Melalui Aplikasi POC Batang Pisang dan Sabut Kelapa. Jurnal Ecosolum, 8(2), 74-85.

Ristekdikti (2020) Info Grafis Flagship Prn 2020-2024. Kementerian Pendidikan dan Kebudayaan, Jakarta

Romiyadi, R., \& Sufiadi, E. (2017). Pengaruh Konsentrasi Air Rendaman Sabut Kelapa dan Dosis Pupuk NPK Terhadap Pertumbuhan dan Hasil Tanaman Melon Varietas Action 434. Paspalum: Jurnal Ilmiah Pertanian, 3(1), 39-50.

Sebastian, B (2019). Pengaruh Pemberian Pupuk Organik Cair Sabut Kelapa Muda Dan Pupuk Gandasil Terhadap Pertumbuhan Dan Produksi Tanaman Okra Hijau (Abelmoschus esculentus). [Script]. Program Studi Agroteknologi Fakultas Pertanian Universitas Medan Area. Medan.
Suriadi (2020) Pengaruh Pemberian Pupuk Organik Cair Sabut Kelapa dan Pemangkasan Cabang Terhadap Pertumbuhan dan Produksi Melon (Cucumis melo L.). [Script]. Fakultas Pertanian. Universitas Sintuwu Maroso. Sulawesi Tengah

Taiz, L., \& Zeiger, E. (2010). Ethylene In: Plant physiology, International edn.

Thor, K. (2019). Calcium-Nutrient and messenger. Frontiers in plant science, 10, 440.10:440. doi: 10.3389/fpls.2019.00440.

Torillo Jr, J. E., \& Mihara, M. A. C. H. I. T. O. (2012). Nitrogen and phosphorus released from coconut husk during retting treatment. International Journal of Environmental and Rural Development, 3(2), 94-98.

Wang, Z., Hassan, M. U., Nadeem, F., Wu, L., Zhang, F., \& Li, X. (2020). Magnesium fertilization improves crop yield in most production systems: a meta-analysis. Frontiers in plant science, 10, 1727. doi: 10.3389/fpls.2019.01727.

Wilman, D., Droushiotis, D., Mzamane, M. N \& Shim, J. S. (2009). The effect of interval between harvests and nitrogen application on initiation, emergence and longevity of leaves, longevity of tillers and dimensions and weights of leaves and 'stems' in Lolium. The Journal of Agricultural Science, 89(1), 65-79. doi: https://doi.org/10.1017/S0021859600027209.

Winarso S (2005) Kesuburan Tanah: Dasar Kesehatan dan Kualitas Tanah. Gava Media. Yogyakarta.

Yan, B., \& Hou, Y. (2018, July). Effect of soil magnesium on plants: a review. In IOP Conference Series: Earth and Environmental Science (Vol. 170, No. 2, p. 022168) .IOP Publishing. doi :10.1088/1755-1315/170/2/022168. 